Süleyman Demirel Üniversitesi Fen Edebiyat Fakültesi Fen Dergisi

Atıf için / For Citation: T. DEMİRAL, M. Y. TEPEBAŞI, F. CALAPOĞLU, A. BÜLBÜL, M. CALAPOĞLU "İn Vitro Çinko Uygulamasının DNA Hasarı, Lipid Peroksidasyonu ve Eritrosit Stabilitesi Üzerine Etkileri”, Süleyman Demirel Üniversitesi Fen Edebiyat Fakültesi Fen Dergisi, 14(2), 316-326, 2019.

\title{
İn Vitro Çinko Uygulamasının DNA Hasarı, Lipid Peroksidasyonu ve Eritrosit Stabilitesi Üzerine Etkileri
}

\author{
Tuğba DEMIRAL ${ }^{1}$, Muhammet Yusuf TEPEBAȘI ${ }^{2}$, Furkan CALAPOĞLU ${ }^{1}$, Ayşe BÜLBÜL ${ }^{1}$, \\ Mustafa CALAPOĞLU* ${ }^{1}$ \\ ${ }^{I}$ Süleyman Demirel Üniversitesi, Fen-Edebiyat Fakültesi, Kimya Bölümü, 32260, Isparta, Türkiye \\ ${ }^{2}$ Süleyman Demirel Üniversitesi, Tıp Fakültesi, Tıbbi Biyoloji ve Genetik AD, 32260, Isparta, Türkiye \\ *yazışılan yazar e-posta: mustafacalapoglu@sdu.edu.tr
}

(Alınış / Received: 25.06.2018, Kabul / Accepted: 30.09.2019, Yayımlanma / Published: 30.11.2019)

Özet: Çinko; büyüme, hücre bölünmesi, metabolizma, yara iyileşmesi, bağışıklık, üreme, tat ve görme fonksiyonlarının işleyişi gibi birçok fizyolojik süreç için gerekli olan iki değerlikli bir geçiş iyondur. Çinko maruziyetinin insan eritrosit zarının bazı özellikleri üzerindeki etkisi in vitro olarak çalışıldı. Ayrıca, insan periferal kan lenfositlerinde, çinkonun genotoksik potansiyelini ortaya koymak için alkali comet analizi yapılmıştır. Farklı derişimdeki tüm $\mathrm{Zn}^{2+}$ çözeltilerinin, doza bağımlı bir şekilde lipit oksidasyonunu inhibe etmede oldukça zayıf bir etki göstermiştir. Eritrositlerin çinko ile inkübasyonunun ardından, çinkonun hücrelerin hemolitik direncini belirgin bir şekilde azalmaya yol açtığını da saptadık. Çalışmalarımız, yüksek derişimde çinkonun insan eritrositleri için toksik olabileceğini ve hemolitik direncin değişmesine neden olabildiğini göstermektedir. Comet sonuçları, kontrolle karşılaştırıldığında yüksek dozlardaki çinko, doz-bağımlı olarak anlamlı düzeyde DNA hasarı oluşturdu $(p<0.05)$. $\mathrm{Bu}$ çalışmanın in vitro verileri yüksek dozda çinko alımının faydadan daha fazla zarara neden olabileceğini düşündürmektedir.

Anahtar kelimeler: Çinko, Membran stabilizasyonu, Genotoksisite, Lipid peroksidasyonu

\section{Effects of In Vitro Zinc Treatment on the DNA Damage, Lipid Peroxidation and Erythrocyte Stability}

\begin{abstract}
Zinc is a divalent transition ion essential for many physiological processes including: the growth and cell division, metabolism, wound healing, immunity, reproduction, functioning of taste and eyesight. The effect of zinc exposure on some properties of the human erythrocyte membrane was studied in vitro. In addition, the alkaline comet assay was used to investigate genotoxicity potential of the zinc in the peripheral blood lymphocytes. In this study, all the various concentrations of $\mathrm{Zn}^{2+}$ solutions showed quite weak efficacy to inhibit lipid oxidation in dose dependent manner. We also detected that incubation of erythrocytes with zinc lead to the marked decrease of haemolytic resistance of the cells. Our studies demonstrate that zinc at higher concentrations may be toxic to human erythrocytes causing changes in the haemolytic resistance. The comet results indicated a significant DNA damage at higher doses after treatment with zinc when compared to controls showing a clear dose-dependent response $(\mathrm{p}<0.05)$. The in vitro data of the present study suggest that high dosage intake of zinc may cause more harm than benefit.
\end{abstract}

Key words: Zinc, Membrane Stabilizing, Genotoxicity, Lipid peroxidation

Tuğba DEMİRAL, tugba_sdu01@hotmail.com, ORCID: https://orcid.org/0000-0001-9745-9368

Yusuf TEPEBAŞI, gultepe74@windowslive.com, ORCID: https://orcid.org/0000-0002-1087-4874

Furkan CALAPOGGLU, furkan61 1189@hotmail.com, ORCID: https://orcid.org/0000-0001-5678-8333

Ayşe BÜLBÜL, ayse_bulbul_06@hotmail.com, ORCID: https://orcid.org/0000-0002-5527-3992

Mustafa CALAPOĞLU, mustafacalapoglu@sdu.edu.tr, ORCID: https://orcid.org/0000-0002-6539-1335 


\section{Giriş}

Çinko özellikle 300'den fazla enzim ve 2000 transkripsiyon faktörü için ko-faktör olarak görev yaptığından insan sağlığı için gerekli minerallerden biridir. Çinko, demir ve bakırdan farklı olarak redoks nötr bir elementtir ve biyolojik reaksiyonlarda Lewis asidi gibi davranmaktadır. Çinkonun bu özelliği nedeni ile yapısal, katalitik ve sinyal bileşenleri olarak anahtar rol üstlenmektedir. Çinkonun proteinler/peptitler ile yapısal olarak ilişkili olduğu, ilk olarak çinkonun insülin ile birlikte kristallenmesiyle doğrulanmıştır [1]. İlk bulunan "Çinko parmak" motifi, Xenopus'un transkripsiyon faktörü TFIIIA'dır [2]. Çinko parmaklar artık 20'den fazla yapısal olarak farklı modül grubuna ayrılmıştır. Bu modüller çeşitli proteinler, lipidler ve nükleik asitlerle etkileşen işlevsel bir motif olarak bilinmektedir [3-5]. Katalitik fonksiyonlarda, çinko güçlü Lewis asidi özelliğinden dolayı negatif yükleri stabilize ederek enzimatik katalizde önemli rol oynamaktadır [6].

Çinko, bütün canlı organizmalarda birçok fizyolojik olaylar için gerekli olmasının yanı sıra halk sağlığ 1 ve klinik anlamlılığı bakımından da oldukça önemli olan bir esansiyel eser elementtir. Çinko desteği için son yıllarda yapılan geniş çaplı randomize kontrollü çalışmalar, popülasyonlarda çinko eksikliğinin yaygın olduğunu ve bu duruma bağlı olarak oluşan halk sağlığı sorununun çözümünde çinko desteğinin önemli olduğunu göstermektedir. Beslenme açısından esansiyel elementlerin alım aralıkları, alımın çok düşük (eksiklik) veya çok yüksek (toksisite) olduğu durumlarda ortaya çıkan sağlık üzerine olumsuz etkileri genellikle basit bir model çerçevesinde tartışılmaktadır. Bir çok yerleşim birimlerini, popülasyonları ve araştırma dizaynlarını içeren çalışmaların ortaya koyduğu genel ortak kan1, diyare, pnömoni ve büyüme bozukluğu görülen hastalara uygulanan çinko desteğinin olumlu tepkiler ile ilişkili olduğudur. Ayrıca bu durum, sağlık masraflarının karşılanmasında bireysel veya toplumsal olarak fon eksikliği ile karakterize edilen sağlik sistemlerinin geçerli olduğu toplumlarda hafif ile orta şiddette çinko eksikliğinin nispeten yaygın olduğu sonucuna yönelik temel kanıtlar ortaya koymaktadır [7].

Tahmini olarak ABD'de nüfusunun \% 15 'i çinkoyu diyet takviyesi olarak kullanmaktadır [8]. Karışık bir diyetle beslenen sağlıklı yetişkinlerde çinko dengesi oluşabilmekte veya günlük $11 \mathrm{mg}$ çinko alımıyla da pozitif çinko dengesi sağlanmaktadır [9]. Çinko; et, bazı sebzeler (fasulye ve nohut) ve fistık gibi gidalarda bulunur. Çoklu vitamin formüllerine eklenmesiyle, çinko alınımı tavsiye edilen günlük alınım değerlerinin birkaç katına kadar ulaşabilmektedir. Ayrıca, alternatif dergilerde ve kitaplarda tanıtılan sağlık yararları nedeniyle de yüksek miktarlarda ilave çinko tüketilebilmektedir. Bununla birlikte, kronik yüksek doz çinkonun insan sağlığ üzerinde ne gibi etkileri olduğu açık değildir.

Günümüzde çinko preparatlarının çeşitli hastalıklar için terapötik ajan olarak kullanımının yanı sıra besin desteği olarak da yoğun tıbbi kullanıma sahip olduğu bilinen bir gerçektir. Ayrıca çinko preparatlarının kullanımı herhangi bir klinik değerlendirme yapılmadan özellikle de çocuklarda besin desteği olarak da kullanılabilmektedir. Çalışmamızda gereksiz veya aşırı çinko kullanımının yanı sıra çinko eksikliğine bağlı olarak ortaya çıkabilecek patolojik durumların, toplum sağlığ üzerine etkilerinin hücresel seviyede değerlendirilmesi amaçlandı. $\mathrm{Bu}$ amaç doğrultusunda, in vitro çinko uygulamasının genotoksik, oksidatif ve eritrosit membran stabilizasyonu üzerine etkilerini ortaya koyarak, çinko fazlalığı ve eksikliğine bağlı 
oluşacak olumsuzlukları tanımlama ve maruziyet ile sonuç arasındaki ilişkiyi ortaya koymayı hedefledik.

\section{Materyal ve Metot}

\subsection{Eritrosit membran stabilizasyonunun belirlenmesi}

Eritrositlerin ozmotik frajilitesi Abad ve arkadaşlarının [10] yönteminde değişikler yapılarak belirlendi. Kısaca, eritrosit paketi oluşturmak için sağlıklı kişiden alınan heparinli kan örneği 3000 rpm'de santrifüjlenerek plazma kısmı atıldı. Elde edilen hücre süspansiyonu Tirisin tamponlu tuz çözeltisi (TBS) ile (146 mM NaCl; 20mM trisin $\mathrm{pH}=7,4) \quad 1: 1(\mathrm{v} / \mathrm{v})$ oranında seyreltilerek $3 \mathrm{kez}$ yıkandı. Her bir yıkama ardından 10 dakika 3000 rpm'de santrifüjlenerek süpernatan kısımları atıldı. Son yıkamanın ardından elde edilen eritrosit paketi 1:1 oranında TBS ile seyreltildi. Hazırlanan eritrosit paketinden $100 \mu \mathrm{L}$ (\% 50 hematokrit) alınarak TBS-çinko (138,56 mM NaCl, 7,64 mM $\mathrm{ZnSO}_{4}, 20 \mathrm{mM}$ tirisin, $\left.\mathrm{pH}=7,4\right)$ çözeltisinin $\mathrm{ddH}_{2} \mathrm{O}$ ile seyreltilmesi sonucu farklı osmolaritede (300-33,33 mOsm/L) ve farklı çinko konsantrasyonlarında hazırlanan 10 $\mathrm{mL}$ çözeltilerine $(40-0,078 \mu \mathrm{g} / \mathrm{mL})$ ilave edildi. Tüpler karıştırıldıktan sonra $37^{\circ} \mathrm{C}$ 'deki su banyosunda inkübe edildiler ve her 15 dakikada bir yavaşça karıştırıldı. Farklı zaman aralıklarında (0-8 saat) tüpler yavaşça homojenize edildikten hemen sonra $1600 \mathrm{x} g$ 'de 10 dakika santrifüj edildi. Santrifüj sonrası oluşan süpernatan kısımları alınarak spektrofotometrede (Shimadzu UV 1601, Japonya) $540 \mathrm{~nm}$ dalga boyunda absorbans değerleri okundu. Hemoliz yüzdesi, her durumda \% 100 hemoliz değerine göre hesapland1. \%100 hemoliz değeri erirositlerin soğuk saf su içerisindeki hemolizi ile elde edildi. Ozmotik frajilite eğrisi, Origin ${ }^{\mathrm{R}}$ programı kullanarak Boltzmann denklemine göre sigmoidal uygunluk ile oluşturuldu. Çalışmamızda eritrosit membranının osmotik kararlılığının değerlendirilmesinde $\mathrm{H}_{50}$ ve $\mathrm{dX}$ parametreleri kullanıldı. Eritrositlerin \% 50 hemoliz olmasını sağlayan ozmolar konsantrasyonlar $\mathrm{H}_{50}$ ve her bir analizde kullanılan eritrositlerin tam lizizinden sorumlu tuz konsantrasyonundaki değişiminin 1/4 ise $\mathrm{dX}$ temsil etmektedir. $\mathrm{H}_{50}$ ve $\mathrm{dX}$ parametreleri hemoliz eğrilerinden hesaplanmıştır (Şekil 1).

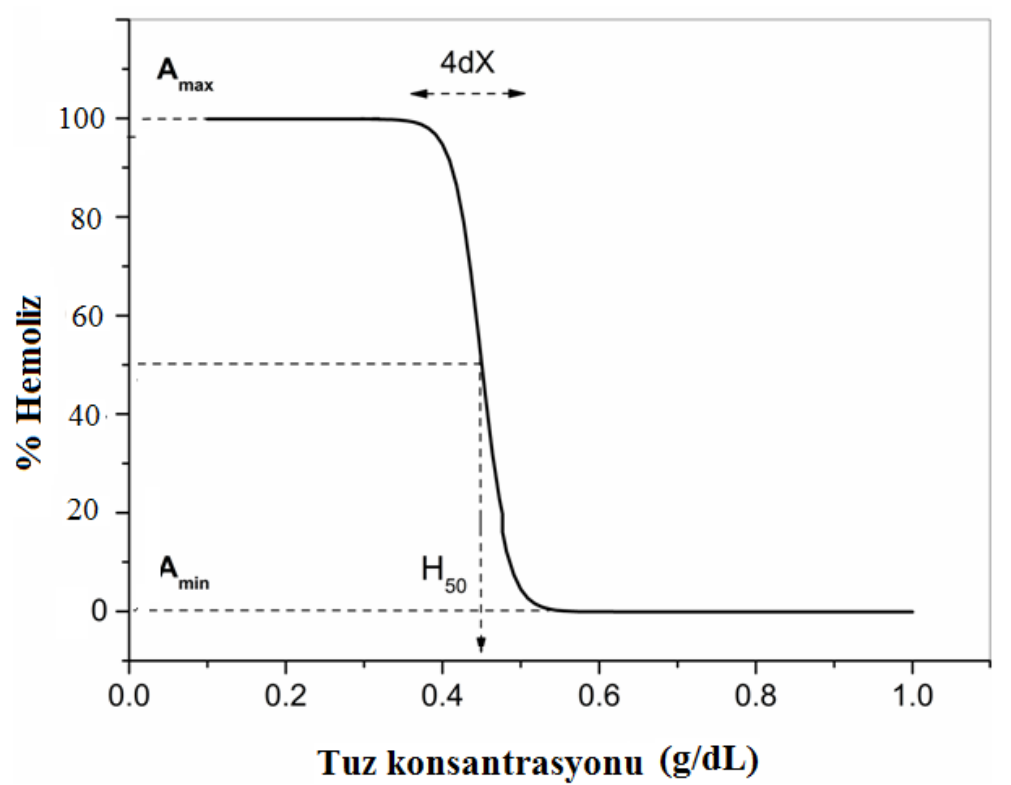

Şekil 1. Eritrositlerin tipik eğrisi tuz konsantrasyonundaki azalma ile oluşan tipik eritrosit hemoliz eğrisi. Veriler sigmoidal regresyon ile düzeltilmiştir. $\mathrm{H}_{50}$, \%50 hemolizi oluşturmak için gereken tuz 
konsantrasyonudur ve $4 \mathrm{dX}$, rezidüel değerden $\left(\mathrm{A}_{\min }\right)$ maksimum absorpsiyon değerine $\left(\mathrm{A}_{\max }\right)$ geçiş ile ilişkili \%100 hemoliz için gerekli olan tuz konsantrasyonundaki değişimdir.

\section{2. $\mathrm{H}_{2} \mathrm{O}_{2}-$ Aractlıklı lipit peroksidasyonu tayini}

TBS-çinko $\left(138,56 \mathrm{mM} \mathrm{NaCl}, 7,64 \mathrm{mM} \mathrm{ZnSO}_{4}, 20 \mathrm{mM}\right.$ tirisin, $\left.\mathrm{pH}=7,4\right)$ stok çözeltisi kullanılarak değişen konsantrasyonlarda $(40-0,078 \mu \mathrm{g} / \mathrm{mL})$ çözeltiler hazırlandı. Negatif kontrol olarak TBS (146 mM NaCl; 20mM trisin $\mathrm{pH}=7,4)$ kullanıldı. Değişen miktarlarda çinko ihtiva eden tüplere son hemoglobin konsantrasyonu $3 \mathrm{~g} / \mathrm{dL}$ olacak şekilde eritrosit paketinden ilave edildi. Tüm seyreltmeler TBS çözeltisi ile yapıldı.

Hazırlanan çalışma ve kontrol tüpleri üzerine son konsantrasyonu $10 \mathrm{mM}$ olacak şekilde $\mathrm{H}_{2} \mathrm{O}_{2}$ ilave edildi. Çalışma tüpleri $37^{\circ} \mathrm{C}$ 'de su banyosunda inkübasyona birakıldı. Değişen zaman aralıklarında (0-16 saat) Stocks ve Dormandy’ye göre MDA tayini yapild 1 [11].

\subsection{Alkalin comet tayini (Alkali Tek Hücre Jel Elektroforezi)}

Alkalin tek hücreli jel elektroforezi (SCGE), farklı konsantrasyonlarda $(40-0,039 \mu \mathrm{g} / \mathrm{ml})$ çinko ile muamele edilen ve muamele edilmeyen lenfosit kültüründe genotoksisite düzeyleri Nandhakumar ve arkadaşlarının metoduna göre belirlendi [12]. Özetle, stok TBS-çinko çözeltisinden $\left(138,46 \mathrm{mM} \mathrm{NaCl}, 7,74 \mathrm{mM} \mathrm{ZnSO}_{4}, 20 \mathrm{mM}\right.$ tirisin, $\left.\mathrm{pH}=7,4\right)$ 40-0,078 $\mu \mathrm{g} / \mathrm{mL}$ 'lik çözeltiler hazırlandı. Hazırlanan her bir çözeltiden sigara içmeyen ve ilaç kullanmayan sağlıklı kişiden elde edilen lenfosit hücrelerinin üzerine $1 \mathrm{~mL}$ ilave edildi. Negatif çözücü kontrol olarak TBS $(146,2 \mathrm{mM} \mathrm{NaCl}, 20 \mathrm{mM}$ trisin, $\mathrm{pH}=7,4)$ çözeltisi kullanıldı. Farklı konsantrasyonlarda çinko içeren lenfosit süspansiyonları, sadece TBS içeren negatif çözücü kontrol lenfosit süspansiyonu ve pozitif kontrol olarak TBS- $\mathrm{H}_{2} \mathrm{O}_{2}$ içeren lenfosit süspansiyonu $37^{\circ} \mathrm{C}$ 'de 1 saat inkübasyona birakıldı. İnkübasyonun ardından tüpler santrifüjlenerek üst faz atıldı ve hücreler PPS ile süspanse edildi. Hücre kültürü süspansiyonundan $50 \mu \mathrm{L}$ alınarak, $\mu \mathrm{L} 50 \% 0.75^{\prime}$ lik (w/v) düşük erime noktası agaroz (LMPA; Sigma-Aldrich) ile karıştırıldı. Ve \% 1'lik (w/v) normal erime noktalı agaroz (NMPA; Sigma-Aldrich) ile kaplanmış slaytlara eklendi. Lamel kapatılarak buzdolabında agaroz katılaşıncaya kadar 15 dak. bekletildi. Lamlara üçüncü tabaka olarak $100 \mu \mathrm{L}$ LMPA yayıldı ve lamel ile kapatılarak buzdolabında agaroz katılaşıncaya kadar 20 dak. beklendi. Lamlar, lizis çözeltisi $\left(2.5 \mathrm{M} \mathrm{NaCl}, 100 \mathrm{mM} \mathrm{Na} 2^{-}\right.$ EDTA, $10 \mathrm{mM}$ Tris, \%10 DMSO, \%1 Triton $\mathrm{X}-100, \mathrm{pH}=10$ ) içinde $4^{\circ} \mathrm{C}$ 'de 2 saat bekletildi. Daha sonra taze hazırlanmış soğuk elektroforez çözeltisinde $(90 \mathrm{~mL} 5 \mathrm{M}$ $\mathrm{NaOH}, 7.5 \mathrm{~mL} 0.2 \mathrm{M}$ EDTA) 20 dak. bekletildi ve 30 dakika boyunca 24 V'de (300 $\mathrm{mA}$ ) elektroforez yapıldı. Nötralizasyondan sonra (0.4 M Tris; $\mathrm{pH} 7.5)$, slaytlar 10 $\mathrm{mg} / \mathrm{ml}$ etidyum bromür ile boyandı ve Lamlar floresan mikroskobunda (Zeiss Axio Imager A1). 400x, büyütme ile tarand1. Her bir çinko seviyesine maruz kalan lökositler için en az 2 SCGE kaydı hazırlandı ve toplamda 50 çekirdek uygulama başına analiz edildi (Open Comet software) [13]. DNA hasarının değerlendirilmesinde Open Comet ile elde edilen \% kuyruk DNA's1 parametresi kullanıldı.

\section{4. İstatistiksel dĕgerlendirme}

İstatistiksel analiz IBM SPSS Statistics 20.0 (IBM Corporation, Armonk, NY, USA) paket program kullanılarak yapıldı. DMSO ile muamele edilen negatif kontrol, $\mathrm{H}_{2} \mathrm{O}_{2}$ ile 
muamele edilen pozitif control BHA ve sentez bileşikleri ile muamele edilen test gruplarının istatistiksel karşılaştırılması ANOVA (tek yönlü varyans) analizi ile yapıldı. Gruplar arası farklılığı ortaya koymak için LSD post-hoc testi kullanıldı. Bütün değerler ortalama \pm SD olarak ifade edildi. İstatistiksel anlamlılık düzeyi için $p<0.05$ kabul edildi.

\section{Bulgular}

Osmotik frajilite testi ile eritrosit membran stabilitesi üzerine çinkonun etkilerinin değerlendirilmesinde kullanılan $\mathrm{H}_{50}$ ve dX değerleri sırasıyla Şekil 2 ve 3 'de verilmiştir.

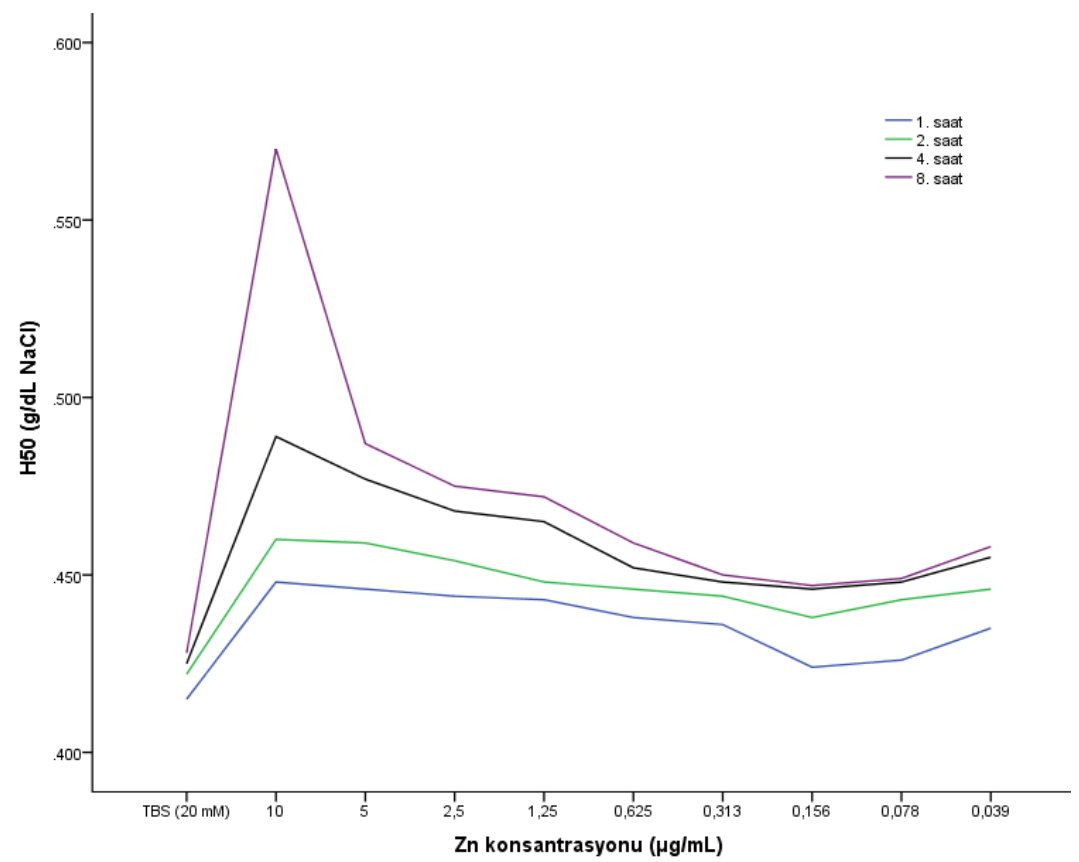

Şekil 2. Farklı konsantrasyonlardaki çinko ile muamele edilen eritrositlerin zamana göre $\mathrm{H}_{50}$ değerleri

Şekil 2 ve 3'deki verilere göre farklı konsantrasyonlarda çinko ile muamele edilen eritrositlerin membran stabilitesi hem zamana ve hem de çinko konsantrasyonuna bağımlı olarak membran stabilitesinde azalma görülmektedir. Ayrıca, yüksek $(>0,313)$ $\mu \mathrm{g} / \mathrm{mL}$ ve düşük $(<0,078 \mu \mathrm{g} / \mathrm{mL})$ çinko konsantrasyonlarında eritrositlerin membran stabilizasyonundaki azalma dikkat çekmektedir. 


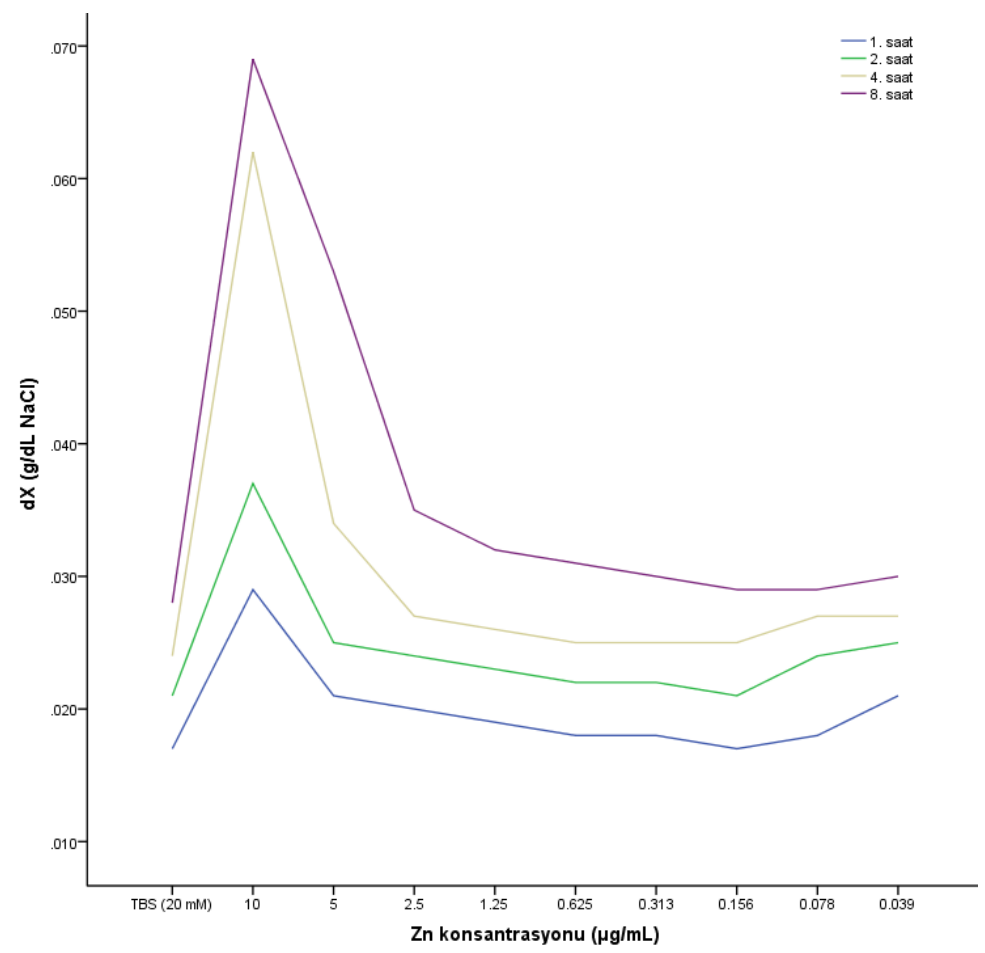

Şekil 3. Farklı konsantrasyonlardaki çinko ile muamele edilen eritrositlerin zamana göre dX değerleri Eritrositlerin $(3 \mathrm{~g} / \mathrm{dL} \mathrm{Hb})$ değişen konsantrasyondaki çinko $(40-0,078 \mu \mathrm{g} / \mathrm{mL})$ ile muamelesinin ardından $\mathrm{H}_{2} \mathrm{O}_{2}$ ile oksidasyonun indüklenmesi ile elde edilen lipid oksidasyonu değerleri Şekil 4'de gösterilmiştir.

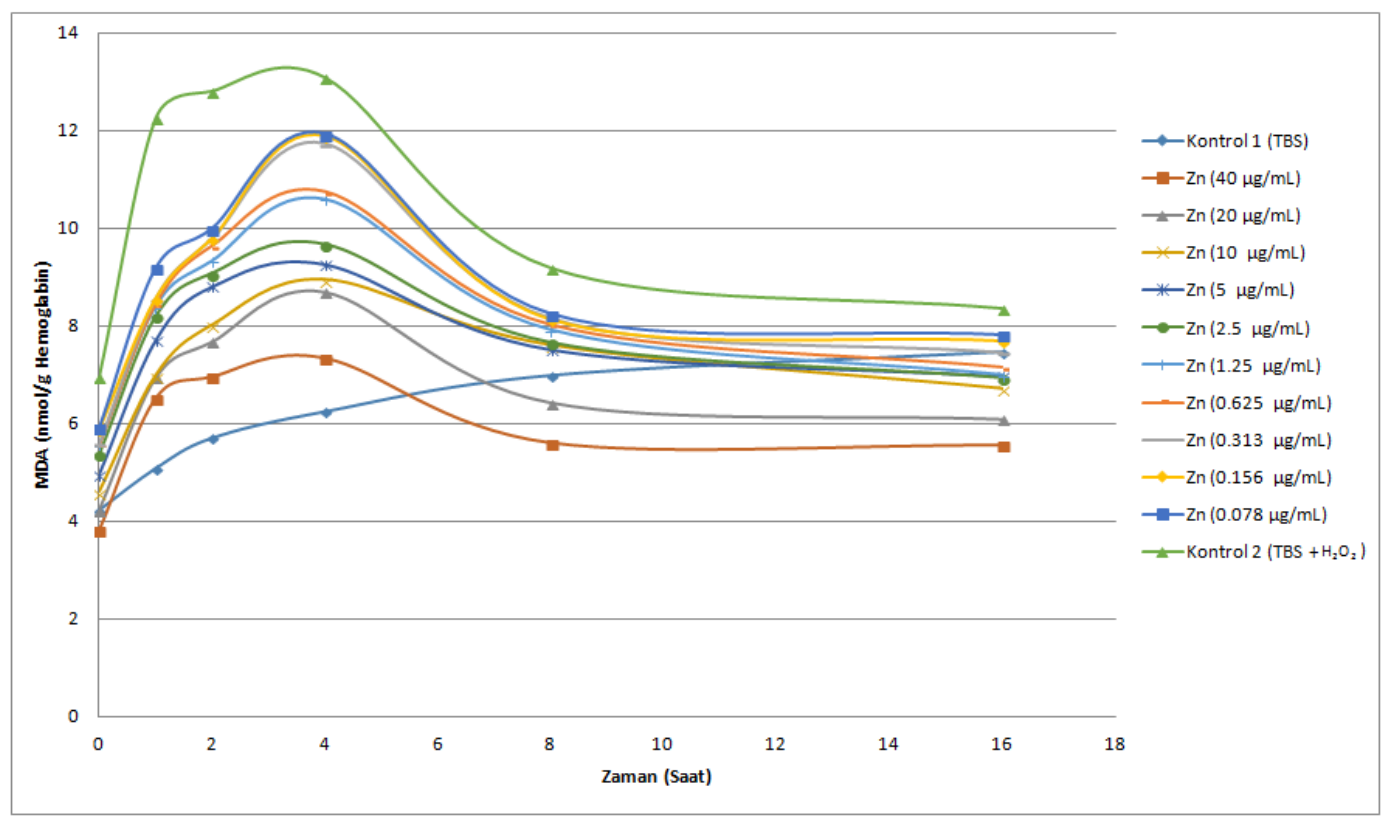

Şekil 4. Çinkonun $\mathrm{H}_{2} \mathrm{O}_{2}$ aracılıklı lipid oksidasyonu üzerine etkisi

Şekil 4'deki grafiğe göre çinko ve $\mathrm{H}_{2} \mathrm{O}_{2}$ içermeyen eritrositlerin (kontrol 1) zamana bağlı olarak oksidasyonun arttığ 1 görülmektedir. Çinko içermeyen ancak $\mathrm{H}_{2} \mathrm{O}_{2}$ içeren eritrositlerin ise zamana bağlı olarak diğer çinko içeren ve içermeyen örneklere göre lipid peroksidasyonu düzeylerinin diğerlerine göre yüksek çıkmıştır. Çinko ihtiva eden eritrosit süspansiyonlarında ise lipit peroksidasyonu artan çinko konsantrasyonuna göre azalma göstermiştir. 
Şekil 5'deki grafiğe göre çinkonun konsantrasyona bağımlı tarzda DNA hasarı oluşturduğu görülmektedir.

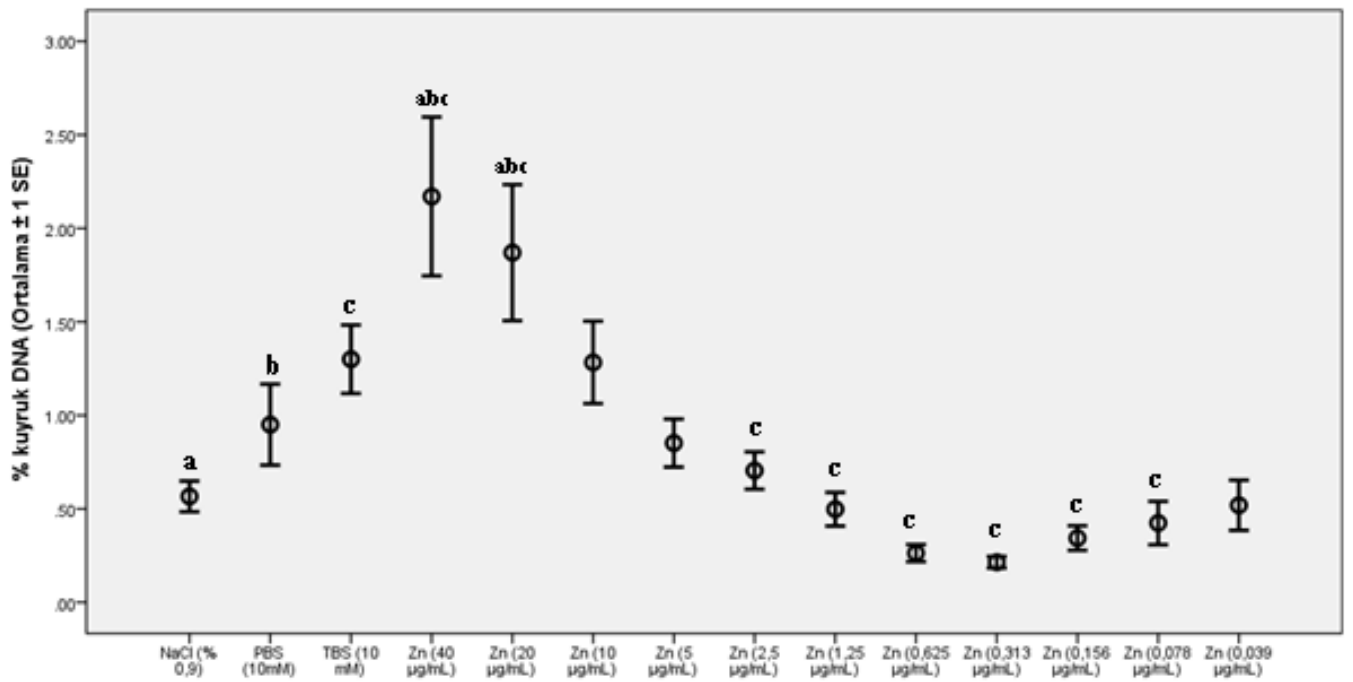

Şekil 5. Farklı konsantrasyonlarda çinko'ya maruz kalan lenfosit hücrelerinden elde edilen \% kuyruk DNA kometi hata çubuk grafiği. Sonuçlar doz başına 100 comet skorlanarak değerlendirme yapılmıştır. Bütün değerler pozitif kontrolün $\left(\mathrm{H}_{2} \mathrm{O}_{2}\right)$ maksimum DNA hasarı miktarına göre belirlenen göreceli skorlarıdır. Aynı hata çubukları üzerindeki farklı üstsimgeler en küçük anlamlı farklar testine (LSD testi) göre anlamlı farklılıklardır.

\section{Sonuç ve Yorum}

Çalışmamızda farklı konsantrasyonlarda hazırlanan $\mathrm{ZnSO}_{4}$ 'ün eritrosit membran bütünlüğü, lipit oksidasyonu ve DNA hasarı üzerine etkileri sırasıyla osmotik frajilite, MDA tayini ve comet tekniği ile değerlendirdik.

Çinko çözeltilerinin hazırlanmasında $\mathrm{ZnSO}_{4}$ 'den hazırlanan farklı çinko çözeltileri, plazma çinko konsantrasyonlarının, yaş gruplarına, cinsiyete ve açlık durumuna göre cut off değerleri göz önüne alınarak hazırlanmıştır ve ayrıca hazırladığımız çinko çözeltileri çinko eksikliği ve fazlalığı durumlarında ortaya çıkacak etkileri gözlemleyebilmek açısından da 10 faklı konsantrasyonda çözelti hazırlanmıştır.

Çinko iyonlarının neden olduğu membran hasarının bir ölçüsü olarak eritrosit hücrelerinin hemolitik direnci belirlendi. Şekil 1'de farklı inkübasyon (1-8 saat) ortamındaki çinko konsantrasyonundaki artışın $(>0,156 \mu \mathrm{g} / \mathrm{mL})$, hücrelerin hemolize daha duyarlı olmasını sağladığını göstermektedir. Ayrıca düşük konsantrasyondaki çinko $(<0,078 \mu \mathrm{g} / \mathrm{mL})$ ile inkübasyona bırakılan eritrositlerin hemolize duyarlılıklarının arttığ1 görüldü. \% 50 hemoliz oluşturan $\mathrm{NaCl}$ konsantrasyonları kontrolde 1. saatte $0,415 \pm 0,006$ olarak bulundu. Bu değer ve tüm çinko ile muamele edilen eritrosit süspansiyonlarındaki değerlerden daha düşük olduğu göze çarpmaktadır. Ayrıca farklı saatlerde yapılan ölçümlerden elde edilen $\mathrm{H}_{50}$ değerleri kontrole göre çinko ile muamele edilen eritrosit süspansiyonlarında yüksek olduğu bulunmuştur. Çalışılan koşullar altında, $0,156 \mu \mathrm{g} / \mathrm{mL}$ çinko ihtiva eden eritrositlerin diğerlerine göre daha yüksek hemoliz direnci gösterdikleri belirlendi (Tablo 1). Çalışmamızda yüksek ve düşük çinko konsantrasyonlarında hemolizin artması diğer bir ifadeyle çinko iyonlarının eritrositlerin hemoliz düzeyine olan etkisi, çinko iyonlarının Band 3 proteininin sitoplazmik alanına bağlanabilmeleri, anyon transport aktivitesini inhibe etme yeteneğine sahip olmaları [14] nedeniyle hücreler ve hücreleri çevreleyen medyum 
arasında iyon değişiminin bozulmasına ve sonuç olarak da hücre hemolizinin artmasına bağlanabilir.

Şekil 2'de 40-0,078 $\mu \mathrm{g} / \mathrm{mL}$ aralığında değişen konsantrasyonlarda hazırlanan çinko çözeltilerinin $\mathrm{H}_{2} \mathrm{O}_{2}$ indüksiyonlu eritrosit lipit oksidasyonu üzerine zamana bağlı etkileri negatif kontrol ve pozitif kontrole göre değerlendirmesi görülmektedir. Şekil 4'deki verilere göre artan çinko konsantrasyonuna bağlı olarak lipit peroksidasyonunda azalma gözlenmiştir. Çalışmamızda eritrosit süspansiyonlarına enzim inhibitörü olarak $\mathrm{NaN}_{3}$ ilave edilmemiştir. Dördüncü saatte kadar yapılan MDA ölçümlerinin yüksek çıkması negatif ve pozitif kontrole göre değerlendirildiğinde $\mathrm{H}_{2} \mathrm{O}_{2}$ 'nin katalaz aracılıklı elimine edilmesindeki sürece bağlı olabileceğini göstermektedir. Bir mikro besin olan çinkonun eritrositlerde hidrojen peroksit-aracılıklı lipit peroksidasyona bakıldığ çinkonun bir lipit peroksidasyonu ürünü olan MDA'nın oluşumunu azalttığı dolayısıyla eritrositlerdeki oksidatif hasarı önlemede etkili olduğu sonucu ortaya çıkmaktadır.

Comet yöntemi, besin maddeleri veya mikro besin maddelerinin genotoksik etkinin belirlenmesi çalışmalarında hassas, ekonomik, pratik, tek hücrede DNA hasarını ortaya koyması ve kısa sürede yapılabilmesi açısından tercih edilen ve sıklıkla kullanılan genotoksik testlerden biridir. Görüntü analizinde operatör tarafından seçilen comet'ler için floresan parametrelerini değerlendiren çok sayıda yazılım paketi mevcuttur. Yazılım paketlerinde comet'lerin değerlendirilmesinde en sık kullanılan parametreler, kuyruk uzunluğu, baş ve kuyrukların göreceli floresan yoğunluğu (normal olarak kuyrukta DNA'nın bir yüzdesi olarak ifade edilir) ve kuyruk momentidir. Ortalama kuyruk uzunluğu, ilk belirleme aşamasında nispeten düşük hasar seviyelerinde artış gösterebildiğinden çok yararlı değildir. Akabinde, kuyruk yoğunluğu artar, ancak hasar dozu arttıkça uzunluk artmaz. Kuyruk uzunluğu arka plan üzerinde belirli bir aşırı floresan yoğunluğu ile tanımlandığından, görüntü analizi programının arka planına veya eşik ayarına da duyarlıdır. Göreceli kuyruk yoğunluğu parametresi, kırılma frekansı için doğrusal bir ilişki ortaya koyduğundan eşik ayarlarından nispeten etkilenmez ve mümkün olan en geniş aralıkta hasarın ayrımcılığına imkan sağladığından (teoride, kuyrukta \%0 ila \%100 DNA) en yararlı parametre olarak gözükmektedir. Bunun aksine, kuyruk momenti parametresi (aslında kuyruk uzunluğu ve kuyruk yoğunluğu ürünüdür) doza göre doğrusal değildir ve comet görünümüne dair herhangi bir izlenim ortaya koymaz [15].

Çinkonun lenfosit DNA'sı üzerine etkileri ortaya koyma amacıyla yapmış olduğumuz comet analizindeki çinko konsantrasyonları, düşük-normal ve yüksek plazma çinko seviyelerini yansıtacak şekilde ayarlandı. Çalışmamızın verilerine göre; çözücü kontrolün (TBS) negatif kontrollere ve $5-0,078 \mu \mathrm{g} / \mathrm{mL}$ çinko ihtiva eden örneklere göre yüksek seviyede DNA hasarı oluşturduğu gözlenmiştir. TBS'ye bağlı DNA hasarı muhtemelen trisinden kaynaklanmaktadır ve 5-0,078 $\mu \mathrm{g} / \mathrm{mL}$ çinko ihtiva eden örneklere göre oluşan DNA hasarı istatistiksel olarak da anlamlıdır $(\mathrm{p}<0,05)$. Yüksek çinko konsantrasyonunda $(20-40 \mu \mathrm{g} / \mathrm{mL})$ oluşan DNA hasarı; konsantrasyona bağımlı olarak hem solvent ve hem de negatif kontrollerden yüksek çıkmış olup, DNA hasarındaki bu artış istatistiksel olarak da anlamlı bulunmuştur $(p<0,005)$. En düşük DNA hasarına ise $0,313 \mu \mathrm{g} / \mathrm{mL}$ çinko konsantrasyonunda ulaşılmıştır ve DNA hasarındaki azalma solvent kontrole göre istatistiksel olarak anlamlı bulunmuştur $(\mathrm{p}<0,05)$. Çinko konsantrasyonunun $0,313 \mu \mathrm{g} / \mathrm{mL}$ 'nin altında olduğu durumlarda ise DNA hasarı çinko konsantrasyonundaki azalmaya bağımlı olarak artış göstermiştir. 
Çinko, çok sayıda makromolekülün yapısı ve fonksiyonunun yanı sıra 300'den fazla enzimatik reaksiyon için esansiyel bir elementtir. İnsan vücudundaki toplam çinko içeriğinin $30 \mathrm{mmol}(2 \mathrm{~g})$ olduğu tahmin edilmektedir ve turnoveri tamamen homeostatik kontrol altındadır. Diyetteki bu mikro besin maddesi ile ilgili olarak yapılan çalışmalar, çinko eksikliğinin büyüme yetersizliği, nöropati, diyare, dermatit, hipotansiyon ve hipertermi ile sonuçlanabileceğini göstermektedir [16-18].

Çinko terapisi akrodermatitis enteropatika ve Wilson's hastalığı olan bireylerde oldukça başarılıdır ve sağlığa bağlı yaşam kalitesi üzerinde oldukça etkilidir. Çinko süplementasyonunun olumlu terapötik cevapları çocuklarda akut diyare, kronik hepatit C, Shigella enfeksiyonu, cüzzam, şark çıbanı ve nezlede gözlenmiştir. Çinkonun bu yegane özellikleri insanlarda görülen çeşitli hastalıklarda anlamlı olarak yararlı terapötik etkilere sahiptir. Özellikle çinko eksikliği ile seyreden hastalıklarda immün sistem aktivitesinin bozulması, oksidatif stresin ve enflamatuar sitokinlerin üretiminin artması gibi çinko eksikliği-uyarımlı değişiklikler klinik tabloyu daha da karmaşık hale getirebilmektedir. Oksidatif stres ve kronik enflamasyon eterosikleroz, çeşitli malignansiler, nörolojik bozukluklar ve otoimmün hastalıklar gibi birçok kronik hastalıkta önemli nedensel rol oynamaktadır [19]. Diğer taraftan aşırı çinko alınımına bağlı olarak akut ve kronik çinko zehirlenmesi oluşabilmektedir. Aşırı çinko hücreler için toksiktir [20]. Dolayısıyla hücresel çinko seviyesinin uygun ranjlar $(0,1$ ve $0,5 \mathrm{mM})$ içersinde tutulması gerekmektedir [21].

Çinko, vücut sıvılarında ve hücrelerde çinko (II) iyonu olarak bulunur ve redoks-inerttir [22]. Yine de, antioksidan özelliklere sahip olduğu yaygın olarak kabul edilmektedir. Çinkonun antioksidan özellikleri dolaylı olarak antioksidan görevi görebileceğinden, "pro-antioksidan" terimi daha uygundur [23]. Bununla birlikte, çinko, sinırlı çinko konsantrasyonları aralığında anti-oksidan fonksiyonları kolaylaştırır. Bu aralığın dışında ise, çinko bir pro-oksidandır. Dolayısıyla da çinko eksikliği ve çinko aşırılığı oksidatif strese ve reaktif oksijen türlerinin fazla üretilmesine neden olabilmektedir [24, 25].

Çinko eksikliğine bağlı oksidatif stresten sorumlu moleküler mekanizmalar, proantioksidan çinko fonksiyonlarının sürdürülmesinin yetersizliğinden kaynaklanmaktadır. Çinko eksikliğinde, genellikle çinkoyu bağlayan ve çinko tamponlamasına katılan hücresel sülfidriller reaktif oksijen türleri oluşturmak üzere bakır ve demir ile tepkimeye girerler. Buna ek olarak, çinko eksikliğinde antioksidan savunmaya katılan metallotiyonein ve enzimlerin uyarılması sonucu durumu daha da kötüleştirmektedir. Yüksek çinko konsantrasyonlarında ise, çinko, tioredoksin ve glutatyon redüktaz gibi antioksidan enzimleri ve reaktif oksijen türlerinde eş zamanlı artışlarla birlikte mitokondriyal solunum zincirinin bileşenlerini (kompleks II ve III) inhibe etmektedir. Ek olarak, yüksek, uzun süreli çinko takviyesi, bir pro-oksidan olan ikincil bakır eksikliğine neden olabilmektedir [7].

Çinkonun anti-oksidan özelliği birçok insan çalışmaları ile ortaya koyulmaya çalışılmıştır. Sağlıklı erişkin gönüllülere 8 hafta boyunca $45 \mathrm{mg}$ çinko/gün takviyesinin oksidatif stres biyobelirteçlerinde azalmaya yol açtığı bulunmuştur [26]. Orta yaşlı ya da yaşlı gönüllülere 12 ay boyunca $45 \mathrm{mg}$ çinko/gün verilmesi durumunda enflamatuar biyobelirteçlerde de azalma görülmüştür [19]. Çinkonun oksidatif stres veya enflamasyon belirteçleri üzerindeki ılımlı artış ve azalma hassasiyetini belirlemek için daha fazla araştırmaya ihtiyaç olduğu yapılan çalışmalarda ifade edilmektedir. 
Çinkonun aynı zamanda çinko eksikliğine bağlı olarak oluşabilecek DNA mutasyonları aracılığı ile kansere yol açabileceği düşünülmektedir. Birçok DNA onarım mekanizmasında çinko önemli yer tutmaktadır. Örneğin, tümör süpresör proteini p53 düşük hücre içi çinko ile işlev kaybına uğramaktadır ve DNA onarımı için sorun oluşturmaktadır [27]. Çinko eksikliğinde, oksidatif stres ve DNA hasarında artma meydana gelmektedir. Bu durum, artan DNA hasarı ile birlikte yetersiz DNA onarım mekanizmaları sinyali nedeniyle daha da kötüleşir. Deney hayvanları ve insanlar üzerindeki çalışmalar, aşırı çinko eksikliğinin veya yetersizliğinin DNA onarımını bozduğunu ve DNA zincir kırıklıklarının sayısını arttırdığını göstermektedir [28]. Yapılan diğer çalışmalarda, Çinko eksikliğine bağlı olarak DNA zincir kırıklarındaki artışın çinko alımındaki değişiklikler ile ortaya çıkmış gibi görünse de, bu kırılmalar çinko eksikliği için spesifik bir biyobelirteç olamayacağını ifade etmektedirler ve bu duruma ilaveten kolin, folat ve niasin'in yetersizliği durumunda da DNA hasarında artış olabileceği vurgulanmaktadır [29, 30]. Diğer bir araştırıcı, özetle, kişilerin çinko ve redoks durumunun birbirleri ile bağlantılı olduğunu ve bu bağlantı durumunun ise hastalık etiyolojisi ve patogenezinde önemli bir faktör olduğunu ileri sürmekle birlikte çinko durumunun oksidatif stres belirteçleri ile değerlendirmesinde ikincil veya ikame faktörü olarak kabul edilmesi gerektiğini ve birçok başka etkenin redoks durumunu değiştirdiğinden, bu oksidatif stres biyobelirteçlerinin çinko durumunun değerlendirilmesi için spesifik olmadığını ifade etmektedir [7].

Türkiye'de çinko eksikliğinin büyüklüğünü gösteren yaygın ve kapsamlı araştırmalar yoktur. Uluslararası araştırmalarda toplumların gelişmişlik durumlarına göre yetersiz çinko alımının \%9,3-\%33,1 arasında değiştiği bilinmektedir. Bebekler, çocuklar, kadınlar ve yaşlı insanlar, yüksek besin gereksinimi veya riskli sindirim ve emilim fonksiyonları nedeniyle marjinal çinko eksikliği riski altında olması oldukça muhtemeldir. Çalışmamızdan elde ettiğimiz sonuçlar, çinko sülfatın $\left(\mathrm{ZnSO}_{4}\right)$, doza bağımlı olarak, marjinal çinko eksikliği de dahil olmak üzere çinko eksikliğinin ve fazlalığının DNA hasarını arttırdığını doğrulamaktadır. DNA bütünlüğünün bozulması ise, bağ 1 şıllık fonksiyonu, kanser ve diğer dejeneratif bozukluklarda yer alan çeşitli işlemler üzerinde önemli bir etkiye sahip olabilir. Bununla birlikte, çinko eksikliğinin giderilmesinde yeterli çinko takviyesinin DNA bütünlüğü üzerindeki bu zararlı etkileri tersine çevirdiği görünmektedir. Bu çalışmanın sonuçları çinko eksikliği, DNA bütünlüğü, oksidatif stres ve DNA onarımı arasında karmaşık in vivo etkileşimlerin olduğunu ve çinkonun DNA bütünlüğünün korunmasında rol oynadığını göstermektedir. Ayrıca, çinko ve çinko tuzlarının eritrosit membranı ve DNA hasarını uyarma etkisi göz önüne alındığında, çinko ve çinko bileşiklerine maruziyetin sağlık açısından dikkate alınması gereken bir durum olduğunu göstermektedir.

\section{Kaynakça}

[1] D. A. Scott, and A. M. Fisher, "The insulin and the zinc content of normal and diabetic pancreas," The Journal of Clinical Investigation, 17 (6), 725-728, 1938.

[2] J. Miller, A. D. McLachan, and A. Klug, "Repetitive zinc-binding doains in the protein transcription factor IIA from Xenopus oocytes," EMBO J., 4 (6), 1609-1614, 1985.

[3] C. Andreini, I. Bertini, and G. Cavallaro, "Minimal functional sites allow a classification of zinc sites in proteins," PLoS One, 6 (10), e26325, 2011.

[4] J. M. Berg and Y. Shi, "The galvanization of biology: A growing appreciation for the roles of zinc," Science, 271 (5252), 1081-1085, 1996.

[5] S. S. Krishna, "Structural classification of zinc fingers: Survey and Summary," Nucleic Acids Res., 31 (2), 532-550, 2003.

[6] W. Maret, "Zinc and Sulfur: A Critical Biological Partnership," Biochemistry, 43 (12), 3301-3309, 2004.

[7] J. C. King, K. H. Brown, R. S. Gibson, N. F. Kreps, N. M. Lowe, J. H. Siekmann, and D. J. Raiten, 
"Biomarkers of Nutrition for Development (BOND)--Zinc Review," J. Nutr., 146 (4), 858S-885S, 2016.

[8] R. R. Briefel, K. Bialostosky, J. Kennedy-Stephenson, M. A. McDowell, R. B. Ervin, and J. D. Wright, "Zinc intake of the U.S. population: findings from the third National Health and Nutrition Examination Survey, 1988-1994.," J. Nutr., 130 (5), 1367S-73S, 2000.

[9] European Food Safety Authority (EFSA) Panel on Dietetic Products, Nutrition and Allergies (NDA) "Scientific Opinion on Dietary Reference Values for zinc," EFSA J., 12 (10), 3844, 2014.

[10] C. Abad, A. Teppa-Garrán, T. Proverbio, S. Piñero, F. Proverbio, and R. Marín, "Effect of magnesium sulfate on the calcium-stimulated adenosine triphosphatase activity and lipid peroxidation of red blood cell membranes from preeclamptic women," Biochem. Pharmacol., 70, (11), 1634-1641, 2005.

[11] J. Stocks and T. L. Dormandy, "The autoxidation of human red cell lipids induced by hydrogen peroxide.," Br. J. Haematol., 20 (1), 95-111, 1971.

[12] S. Nandhakumar, S. Parasuraman, M. M. Shanmugam, K. R. Rao, P. Chand, and B. V. Bhat, "Evaluation of DNA damage using single-cell gel electrophoresis (Comet Assay)," J. Pharmacol. Pharmacother., 2 (2), 107-111, 2011.

[13] B. M. Gyori, G. Venkatachalam, P. S. Thiagarajan, D. Hsu, and M. V. Clement, "OpenComet: An automated tool for comet assay image analysis," Redox Biol., 2 (1), 457-465, 2014.

[14] Y. P. Tu and H. Xu, " $\mathrm{Zn}^{2+}$ inhibits the anion transport activity of Band 3 by binding to its cytoplasmic tail," Biosci. Rep., 14 (4), 159-169, 1994.

[15] A. R. Collins, "The comet assay for DNA damage and repair," Mol. Biotechnol., 26 (3), 249-261, 2004.

[16] A. Jenner, M. Ren, R. Rejendran, P. Ning, B. T. K. Huat, F. Watt, and B. Halliwell, "Zinc supplementation inhibits lipid peroxidation and the development of atherosclerosis in rabbits fed a high cholesterol diet.," Free Radic. Biol. Med., 42 (4), 559-566, 2007.

[17] H. Tapiero and K. D. Tew, "Trace elements in human physiology and pathology: zinc and metallothioneins," Biomed. Pharmacother., 57 (9), 399-411, 2003.

[18] S. Taysi, F. Akcay, C. Uslu, Y. Dogru, and I. Gulcin, "Trace elements and some extracellular antioxidant protein levels in serum of patients with laryngeal cancer," Biol. Trace Elem. Res., 91 (1), 11-18, 2003.

[19] A. S. Prasad, F. W. Beck, B. Bao, J. T. Fitzgerald, D. C. Snell, J. D. Steinberg, and L. J. Cardozo, "Zinc supplementation decreases incidence of infections in the elderly: Effect of zinc on generation of cytokines and oxidative stress," Am. J. Clin. Nutr., 85 (3), 837-844, 2007.

[20] A. Pagani, L. Villarreal, M. Capdevila, and S. Atrian, "The Saccharomyces cerevisiae Crs5 Metallothionein metal-binding abilities and its role in the response to zinc overload," Mol. Microbiol., 63 (1), 256-269, 2007.

[21] D. J. Eide, "Zinc transporters and the cellular trafficking of zinc," Biochimica et Biophysica Acta Molecular Cell Research, 1763 (7), 711-722, 2006.

[22] T. M. Bray and W. J. Bettger, "The physiological role of zinc as an antioxidant," Free Radic. Biol. Med., 8 (3), 281-291, 1990.

[23] W. Maret, "Metallothionein redox biology in the cytoprotective and cytotoxic functions of zinc," Experimental Gerontology, 43 (5), 363-369, 2008.

[24] D. J. Eide, "The oxidative stress of zinc deficiency.," Metallomics, 3 (11), 1124-9, 2011.

[25] P. I. Oteiza, K. L. Olin, C. G. Fraga, and C. L. Keen, "Zinc deficiency causes oxidative damage to proteins, lipids and DNA in rat testes.," J. Nutr., 125(4), 823-9, 1995.

[26] A. S. Prasad, B. Bao, F. W. J. Beck, O. Kucuk, and F. H. Sarkar, "Antioxidant effect of zinc in humans," Free Radic. Biol. Med., 37 (8), 1182-1190, 2004.

[27] E. Ho, "Zinc deficiency, DNA damage and cancer risk," J. Nutr. Biochem., 15 (10), 572-578, 2004.

[28] Y. Song, S. W. Leonard, M. G. Traber, and E. Ho, "Zinc deficiency affects DNA damage, oxidative stress, antioxidant defenses, and DNA repair in rats.," J. Nutr., 139 (9), 1626-31, 2009.

[29] J. B. Kirkland, "Niacin requirements for genomic stability," Mutation Research - Fundamental and Molecular Mechanisms of Mutagenesis, 733 (1-2), 14-20, 2012.

[30] S. H. Zeisel, "Nutritional Genomics: Defining the Dietary Requirement and Effects of Choline," $J$. Nutr., 141 (3), 531-534, 2011. 